\title{
Mod en brugbar økonomisk tænkning om Afrika
}

\section{Af Morten Jerven}

Gennem de seneste to årtier har mainstream økonomer, der studerer afrikansk økonomisk vækst, forsøgt at forklare noget, der aldrig har fundet sted. Økonomer har næsten udelukkende fokuseret på ét spørgsmål: Hvorfor har den økonomiske vækst slået fejl i Afrika?

Spørgsmålet er ikke kun et akademisk tidsfordriv; den opfattelse har vundet indpas i flere populære fora. Mest berømt i 2000, da The Economist på forsiden afbildede Afrika som et håbløst kontinent, der var ude af stand til at opleve økonomisk vækst og udvikling. I en særlig reportage fra kontinentet spurgte magasinet 'Har Afrika en iboende karakterbrist, der fastholder det som tilbagestående og ude af stand til udvikling?'

Blot ti år senere have The Economist en helt anden forsidehistorie om Afrika som et håbefuldt kontinent på vej op. Hvordan kunne de have taget så meget fejl første gang? I 2000 påpegede Johannesburgs ugentlige erhvervsmagasin Financial Mail, at i 1997, blot tre år tidligere, havde The
Economist skrevet, at 'Afrika syd for Sahara er i bedre form end det har været i en generation'. Financial Mail stillede spørgsmålet: 'Har redaktørerne af The Economist en karakterbrist, der gør dem ude af stand til at foretage konsekvente vurderinger?'

Som Bob Dylan fortalte os, behøver man ikke en meteorolog til at fortælle, hvilken vej vinden blæser. The Economist er blot et populært nyhedsmagasin, så man skal måske ikke være for overrasket over, at dets vurderinger varierer og vender med strømmen. I år 2000 kunne redaktionen se tilbage på to årtiers nyhedshistorier fra Afrika, der fokuserede på hungersnød, borgerkrige og fiasko. Magasinets perspektiv i år 2000 var i høj grad et barn af sin tid. Men det var en forhastet vurdering, der ignorerede fundamentale elementer i afrikansk økonomisk udvikling.

Men fra 'vejrmændene' i fortællingen om Afrikas udvikling - faktiske økonomer ville man forvente en vurdering, der bygger på langsigtede mønstre og historie, og som står sin prøve. Men økonomer fortsætter med at fejlvurdere Afrika. Hvor meget fejl

Morten Jerven er professor i udviklingsstudier ved Norges miljø- og biovitenskapelige universitet. Han har en ph.d. i økonomisk historie fra London School of Economics og har skrevet flere bøger om Afrikas økonomiske udvikling. Hans bøger er baseret på studier i Ghana, Nigeria, Uganda, Kenya, Tanzania, Malawi, Zambia and Botswana. 
de tager - og hvorfor de hele tiden tager fejl af den økonomiske vækst i Afrika - er emnet for min bog Afrika: Hvorfor økonomer tager fejl.

\section{Som Bob Dylan fortalte os, behøver man ikke en meteorolog til at fortælle, hvilken vej vinden blæser.}

Da redaktørerne på The Economist erklærede, at Afrika var håbløs, stak de ikke bare en finger i vejret for at se, hvilken vej vinden blæste; de gjorde det med inspiration fra den herskende konsensus i den økonomiske litteratur på daværende tidspunkt. Siden 1990'erne havde næsten alle økonomiske studier af Afrika fokuseret på at forklare, hvorfor der var et 'kronisk fravær af vækst' på dette kontinent.

I 2007 identificerede Paul Collier den 'nederste milliard', den del af verdens befolkning som (ifølge Collier) lever i lande, som ikke oplever økonomisk vækst. Han udpegede lige under 60 lande, som han kaldte Afrika+.

Set i bakspejlet er det slående, at denne udtalelse faldt lige efter en periode med hurtig økonomisk vækst siden midten af 1990 'erne i netop de økonomier, som Collier talte om. De fleste af de økonomier, som Collier beskrev som kroniske fiaskoer, havde oplevet vækst i mere end et årti. Mange af landenes økonomier voksede før, efter og selv i løbet af den tid, hvor Collier skrev sin bog. Så mit spørgsmål er: hvordan kunne økonomer overse årtiers økonomiske vækst?

\section{Den afrikanske 'dummy'}

Svaret skal findes i de anvendte metoder. Vi er nødt til at gå tilbage til en skelsættende artikel af Robert J. Barro fra 1991. Han foreslog en model, der senere skulle blive kernen i det, der er blevet kaldt 'regressionsindustrien'. Han ønskede at udforske de afgørende faktorer for økonomisk vækst ved hjælp af en omfattende global stikprøve af lande. På den ene side af ligningen satte han den gennemsnitlige vækstrate i landene, og på den højre side af ligningen foreslog han en række variabler, som en mulig forklaring på variationen i de gennemsnitlige vækstrater.

Men efter at have tilføjet en række af sådanne variabler til at opfange forskelle i politiske regimer, uddannelsesniveau og politisk uro, havde Barro stadig et uforklarligt residual. Han tilføjede også en 'dummy variabel' for det afrikanske kontinent. Dummy variablen antog værdien 1 , hvis landet var afrikansk, og 0, hvis landet ikke var afrikansk. Han fandt en signifikant negativ afrikansk dummy variabel, og hans fortolkning var, at analysen endnu ikke fuldt ud havde opfanget de særlige kendetegn ved et 'typisk' afrikansk land.

Derpå fulgte et årtis forskning i at eliminere den 'afrikanske dummy'. Målet var at finde en variabel, der opfangede denne karakterbrist i de afrikanske lande. Mange variabler blev foreslået og fundet at korrelere med gennemsnitlig lav vækst - en undersøgelse viste, at intet mindre end 145 variabler er blevet foreslået som determinanter for vækst. Problemet er, at korrelation ikke indebærer årsagssammenhæng. Lad os tage en af de foreslåede variabler: høj bistandsafhængighed. Man kunne altså plausibelt argumentere for, at høj afhængighed af udviklingsbistand er dårligt for væksten, fordi det betyder, at stater er orienterede mod omverdenen, at de ikke fokuserer på at levere offentlige goder til gengæld for opkrævede skatter osv. Det er alt sammen fint, men holder det som en årsag til langsom vækst på det afrikanske kontinent?

Det gør det ikke. Det bryder med den 
første regel; årsag bør gå forud for effekt. Hvis man ser på data, vil man se, at målte satser for officiel udviklingsbistand som en andel af BNP kun har været forholdsvis høj siden 1980’erne og 1990’erne, mens udviklingsbistandens andel af BNP tidligere var forholdsvis lav. Det giver således ikke mening, at udviklingsbistanden skulle have forårsaget langsom vækst - snarere er det modsatte tilfældet; det lader til, at den målte høje afhængighed af udviklingsbistand bedst forklares som et resultat af langsom vækst i 1980'erne og 1990'erne. Andre korrelater såsom budgetunderskud, høje gevinster på det sorte marked eller subjektive mål for kvaliteten af de politiske institutioner led af nøjagtigt samme fejl. Observationer hentet fra 1980'erne og 1990'erne blev benyttet som forklaringsmodel for hele perioden.

Den grundlæggende fejl i disse modeller er, at de udelukkende fokuserede på at forklare det gennemsnitlige fravær af vækst i Afrika. Det betød, at registrerede fald i 1980'erne og stagnation i 1990'erne helt overskyggede de fremskridt, der blev gjort i 1960'erne og 1970'erne. Ikke kun gav det et fejlagtigt og overdrevent pessimistisk billede af de økonomiske præstationer i de afrikanske økonomier, det gjorde også, at den ortodokse økonomiske litteratur meget bekvemt undgik nogle af de svære spørgsmål.

Hvordan kan vi forklare, at såkaldte 'dårlige' økonomiske politikker i 1960'erne og 1970 'erne faldt sammen med gode økonomiske præstationer, hvorimod indførelsen af 'gode' økonomiske politikker og politisk styring i 1980'erne og 1990'erne korrelerede med økonomisk stagnation og politisk uro? Denne økonomiske analyse gav opbakning til at gennemføre liberale politikker i 1980'erne og 1990'erne, men økonomiske data viser, at væksten først vendte tilbage, da de økonomiske forhold i verden bedredes i slutningen af 1990 'erne. I stedet for at favne det modstridende i dette mønster, hvilket ville have indebåret at sætte spørgsmålstegn ved nogle af disse modellers grundlæggende antagelser samt bevisernes gyldighed, fortsatte den økonomiske mainstream-litteratur med at acceptere 'kronisk fravær af vækst' som en kendsgerning.

\section{Afrikas særlige kendetegn}

I andengenerations-litteraturen om vækst var den centrale problemstilling ikke længere hvorvidt 'dårlig' økonomisk politik korrelerede med dårlige økonomiske præstationer. Spørgsmålet var snarere, hvilken karakterbrist disse lande besad, som foranledigede dem til vedholdende at forfølge politikker, der var dårlige for væksten. Det var denne litteratur der inspirerede The Economist's lederartikel i 2000.

The Economist anvendte en række forskellige datasæt, der skulle tage højde for nogle af Afrikas særlige kendetegn - det være sig høj etnisk fragmentering, arv fra kolonitiden, slavehandlen eller forekomst af malaria eller andre sygdomme. Det er også i denne afsøgning af variabler fra fortiden, at det blev klart, at institutioner og historie har betydning for den økonomiske udvikling.

En lang række rammebetingelser eller historiske hændelser er forsøgt gjort kvantificerbare. Man har fundet, at antallet af bosættere fra kolonimagterne, forskellige sproggrupper, antal slaver og andre variabler i datasæt efterladt af antropologer, kolonialister eller historikere korrelerer med indkomst i dag. Disse værker er ikke interesserede i at forklare økonomisk vækst; de er interesserede $i$ at forklare forskellen i indkomstniveauer mellem nationer i dag. Deres fokus er på at finde de bagvedliggende årsager til, at nogle lande har fejlet. 
Så fremfor at forklare hvorfor eksempelvis økonomien i Tanzania voksede med én pct. hvert år fra 1960 til 1990, mens økonomien i Japan voksede med fire pct., ser de i stedet på variabler, der kan forklare forskellen i BNP per indbygger på, lad os sige 1.000 dollar i Tanzania og 20.000 dollar i Japan i år 2000. De foreslår, at årsagen til forskellen er, at Tanzania var udsat for kolonistyre og arvede 'dårlige' institutioner, mens Japan ikke var udsat for den 'forkerte' type kolonistyre og derfor sikret økonomisk velstand gennem sine 'gode' institutioner.

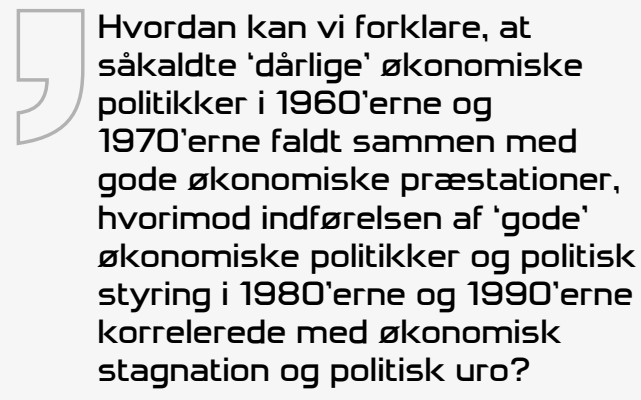

Men for tanzanianere er forskellen på 500 og 1.000 dollar mere relevant, og det vigtigste mål bør være, hvordan man når 2.000 dollar eller på anden måde oplever en vedvarende og betydelig forbedring af levestandarden. Det er ikke kun nytteløst at opdage, at forskellen mellem Tanzania og Japan kan forklares med økonometri ved at henvise til en variabel, der opfanger etnisk fragmentering, kvaliteten af forvaltningen eller geografisk placering, det er også baseret på dårlig samfundsvidenskab.

\section{Hvorfor tager økonomer fejl}

I min bog Afrika: Hvorfor økonomer tager fejl viser jeg, hvordan denne dårlige videnskabelige praksis har betydet, at den økonomiske vækstlitteratur har misforstået vækst i Afrika. Hvor det plejede at for- holde sig sådan, at fokus altovervejende var på den afrikanske væksttragedie, ændrede dette sig pludselig til, at nogle forskere, men især medier og analytikere, ukritisk begyndte at omfavne den 'Africa Rising'-hype, der opstod i slutningen af 00 'erne. Et af de hyppigst gentagne udsagn til støtte herfor var, at 'Syv ud af ti hurtigst voksende økonomier befinder sig i Afrika.' I virkeligheden er dette både en langt mindre præcis og langt mindre imponerende statistik, end det lyder. Mere generelt har fortællinger om afrikansk økonomisk udvikling en tendens til at være løst forbundet til fakta og i højere grad drevet af hype.

'Syv ud af ti' stammer fra en data-øvelse udført i 2011 af The Economist. Øvelsen udelukkede lande med en befolkning under 10 mio. samt post-konflikt lande som Irak og Afghanistan. Dette efterlod 81 lande, 28 af dem i Afrika (over 30 pct.), og hvis man fjerner OECD-landene, (som sandsynligvis ikke vil vokse med mere end 7 pct. om året), vil man opleve, at hver anden økonomi i undersøgelsen befinder sig i Afrika. Det ville nok ikke have den samme retoriske effekt at sige: "i gennemsnit forventes nogle afrikanske økonomier at vokse lidt hurtigere end andre ikke-OECD-lande", men det ville være mere korrekt.

Før vi kommer for godt i gang (The Economist refererede prognoser for 2011 til 2015), så er der forskel på prognoser og faktisk målt vækst. Ifølge økonomen John Kenneth Galbraith er den eneste funktion af økonomiske prognoser at få astrologi til at fremstå respektabelt. Så hvor gode er IMF egentlig til at lave prognoser for vækst i lavindkomstlande?

Ifølge deres egen vurdering overvurderede IMF's prognoser væksten i BNP og undervurderede inflationen. Et andet stu- 
die undersøgte forskellen mellem prognoserne og den efterfølgende vækst-revision i lavindkomstlande og fandt, at "revisioner af output-data i lavindkomstlande i gennemsnit er større end i andre lande ...." Prognoser er systematisk optimistiske over hele verden, men dette er endnu mere udtalt i lavindkomstlande.

På listen over de hurtigst voksende økonomier var lande som Nigeria, Ghana og Etiopien. Nyheden om, at både Nigerias og Ghanas BNP fordobledes, efter at man indførte et nyt udgangsår for beregning af BNP i 2010 og 2014, bør minde os om unøjagtigheden i disse vækstoverslag. Hvor meget tiltro bør man have til en vækstrate på syv pct., når 50 pct. af økonomien ligger uden for det officielle udgangspunkt? De senere års vækst $\mathrm{i}$ lande med forældede basisår overvurderes også.

Mens Ghana efter sigende har haft de højeste vækstrater i verden i de seneste år, bemærkede en ekspertvurdering af Ghanas nationalregnskaber, at "der hverken er blevet udført en national opgørelse over landbruget eller foretaget andre undersøgelser af fx afgrøder og dyrebesætninger ... der findes ingen undersøgelser, der kan fungere som udgangspunkt for byggeri, indenrigshandel og service". Det blev for nylig rapporteret, at der er planlagt en økonomisk opgørelse næste år. Det vi ved er, at Ghana (sammen med Zambia, et andet af de 'top ti vækstlande', der er blevet præsenteret) har henvendt sig til IMF med anmodning om assistance i kølvandet på deres debut på de internationale lånemarkeder.

Det meste af tiden ved vi simpelthen ikke nok til at kunne påstå nøjagtige vækstrater. Der er også kendte skævheder og manipulationer. Etiopien er fx kendt for sine langvarige uoverensstemmelser med IMF om deres vækstrater. Mens de officielle tal i det seneste tiår har været tocifrede, har en grundig analyse antydet, at den faktiske årlige vækst lå på omkring fem til seks pct. Mere generelt brugte et studie satellitbilleder af natlys til at beregne alternative vækstrater og fandt, at autoritære regimer overdriver vækstrater med ca. 0,5 til 1,5 procentpoint. Et andet studie hævder, at inflationen systematisk undervurderes i afrikanske lande - hvilket medfører, at vækst og fattigdomsbekæmpelse overvurderes.

Skævheder i data overføres fra økonomisk vækst til andre målinger. Presset på forskere, journalister og andre kommentatorer til at sige noget generelt om 'Afrika' er ubarmhjertigt, og generelt imødekommes det villigt. Når man taler om gennemsnitlige tendenser i afrikansk politik og opinion, påvirkes analysen af tilgængeligheden af data som fx Afrobarometer, og tilgængelige data er forudindtaget.

Enhver kvantitativ undersøgelse, der udtaler sig om forholdet mellem vækst og tendenser inden for ulighed og fattigdom, er afhængig af tilgængeligheden af data. En artikel udtalte dristigt, at fattigdommen i Afrika er for nedadgående ... meget hurtigere end man tror! Datagrundlaget var meget sparsomt og ujævnt fordelt. Der manglede data for Angola, Congo, Comorerne, Kap Verde, D.R. Congo, Eritrea, Ækvatorialguinea, Seychellerne, Togo, Sao Tomé og Principe, Tchad, Liberia og Sudan. Derudover var seks lande kun dækket af en enkelt undersøgelse. Databasen indeholdt ingen observationer siden 2004 - så udviklingen var udelukkende baseret på formodning. Som bekendt behøver man mindst to punkter for at trække en linje. Ikke desto mindre indeholdt undersøgelsen en graf over fattigdomsgrænser i Den Demokratiske Republik Congo fra 1970 til 2006 - baseret på nul datapunkter.

Som følge af tvivl om nøjagtigheden af 
de officielle tal og manglende oversigt over indkomstfordeling har forskere vendt sig mod andre målinger. Data om adgang til uddannelse og besiddelse af forbrugsgoder såsom fjernsyn blev brugt til at sammensætte nye indekser for aktiver. Disse data blev så sat i stedet for økonomisk vækst og mål på middelklassen. I begge tilfælde kan dataene tegne et misvisende positivt billede. Selv om man hæuder at beskrive hele Afrika gennem de sidste to årtier, er disse undersøgelser kun tilgængelige for nogle lande i nogle perioder.

\section{Fra 'Bottom Billion' til 'Africa Rising'}

På grund af manglende opmærksomhed på historiske data om økonomisk vækst blev det længe hævdet, at Afrika lider af 'et kronisk fravær af vækst', men vækst er ikke nyt for de afrikanske økonomier, væksten har været tilbagevendende. Der er ingen tvivl om, at der er flere varer, der forlader og kommer ind på det afrikanske kontinent i dag end for femten år siden. Flere veje og hoteller bliver bygget og mere kapital flyder ind og ud af det afrikanske kontinent end før. Men hvad er det virkelige tempo for økonomisk vækst? Kommer stigningen i transaktionsvolumen til udtryk i en vedvarende øgning af levestandarden? Dataene giver os endnu ikke et tydeligt svar. Det er forskernes opgave at komme med nøgterne vurderinger, der navigerer mellem opspind og det troværdige.

For tiden er den almindelige økonomiske litteratur i stand til at forklare, hvorfor afrikanske økonomier ikke vokser, hvorfor de slår fejl, og hvorfor de sidder fast i fattigdomsfælder. Problemet er bare, at de afrikanske økonomier er vokset i omkring to årtier, og at dette ikke er noget nyt; væksten har været tilbagevendende i Afrika, ikke fejlslagen. Særligt frustrerende og en hindring for objektiv vurdering er, at fortællingerne om Afrikas økonomiske udvikling skifter fra den ene yderlighed til den anden så hurtigt. Sandheden ligger et sted mellem 'miraklerne' og 'tragedierne'. Det er slående, at i løbet af 3-4 år er den mest berømte sætning vedrørende afrikanske økonomier gået fra 'Bottom Billion' til ‘Africa Rising.'

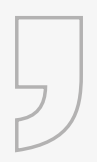

\section{Det er slående, at i løbet af 3-4 år er den mest berømte sætning vedrørende afrikan- ske økonomier gået fra 'Bot- tom Billion' til 'Africa Rising'.}

En yderligere forstyrrende tendens i studiet af makroøkonomi i Afrika er den stigende afstand mellem observatør og det observerede. Mens landestudier var normen i 1970'erne og 1980'erne, har disse veget pladsen for vækstregressioner på tværs af lande, med globale datasæt. Det betyder, at der kun er få måder, hvorpå man kan dobbelttjekke, om virkeligheden og datasættene stemmer overens.

Jeg mener, at kernen i problemet er, at størstedelen af den makroøkonomiske litteratur, som benytter sig af afrikanske eksempler, studerer 'økonomi' i stedet for 'økonomier'. Den primære interesse har været rene kausale resultater og at finde lovmæssigheder og generelle udsagn. Det betyder ofte, at relevans og lokal anvendelsesmulighed går tabt. Hvis litteraturen er korrekt, betyder det ironisk nok, at globale stikprøveregressioner bør opgives til fordel for dybe kontekstuelle studier af historie og institutioner. Udfordringen er at bevare nationaløkonomiens relevans for de økonomier, den hævder at studere. 